\title{
Author Correction: Endogenous FGF21-signaling controls paradoxical obesity resistance of UCP1- deficient mice
}

Susanne Keipert (1), Dominik Lutter (1), Bjoern O. Schroeder (1D, Daniel Brandt, Marcus Ståhlman, Thomas Schwarzmayr, Elisabeth Graf, Helmut Fuchs (1), Martin Hrabe de Angelis (1), Matthias H. Tschöp (D), Jan Rozman (1) \& Martin Jastroch

Correction to: Nature Communications https:/doi.org/10.1038/s41467-019-14069-2, published online 31 January 2020.

The original version of the Peer Review File associated with this Article was updated after publication to redact two figures in the interest of confidentiality.

Published online: 16 March 2021

\section{Additional information}

Supplementary information The online version contains supplementary material available at https://doi.org/10.1038/s41467-021-22119-x.

\footnotetext{
(c) (i) Open Access This article is licensed under a Creative Commons Attribution 4.0 International License, which permits use, sharing, adaptation, distribution and reproduction in any medium or format, as long as you give appropriate credit to the original author(s) and the source, provide a link to the Creative Commons license, and indicate if changes were made. The images or other third party material in this article are included in the article's Creative Commons license, unless indicated otherwise in a credit line to the material. If material is not included in the article's Creative Commons license and your intended use is not permitted by statutory regulation or exceeds the permitted use, you will need to obtain permission directly from the copyright holder. To view a copy of this license, visit http://creativecommons.org/licenses/by/4.0/.
}

(C) The Author(s) 2021 